This item was submitted to Loughborough's Research Repository by the author.

Items in Figshare are protected by copyright, with all rights reserved, unless otherwise indicated.

\title{
Anti-dialogic positioning in change stories: bank robbers, saviours and peons
}

PLEASE CITE THE PUBLISHED VERSION

http://dx.doi.org/10.1177/1350508409102299

\section{PUBLISHER}

Sage Publications / @ The Author(s)

\section{VERSION}

AM (Accepted Manuscript)

\section{LICENCE}

CC BY-NC-ND 4.0

\section{REPOSITORY RECORD}

Beech, Nic, Stacy A. MacPhail, and Christine Coupland. 2019. "Anti-dialogic Positioning in Change Stories: Bank Robbers, Saviours and Peons”. figshare. https://hdl.handle.net/2134/14835. 
This item was submitted to Loughborough's Institutional Repository (https://dspace.lboro.ac.uk/) by the author and is made available under the following Creative Commons Licence conditions.

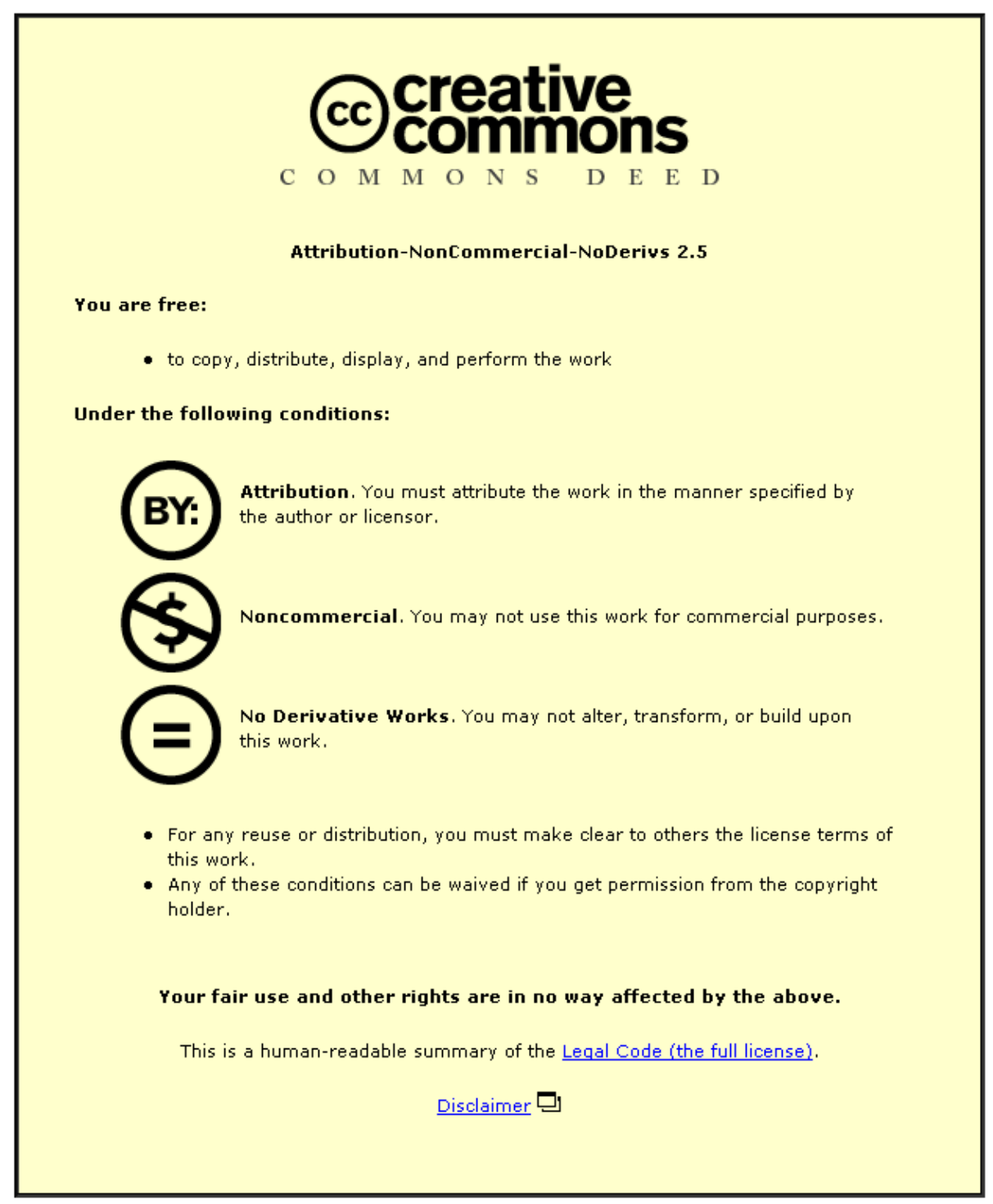

For the full text of this licence, please go to: http://creativecommons.org/licenses/by-nc-nd/2.5/ 
Beech, N., MacPhail, S.A. and Coupland, C. (2009) Anti-dialogic positioning in change stories: Bank robbers, saviours and peons. Organization, 16(3): 335-352

\begin{abstract}
Stories people tell of going through change incorporate and react to others around them. Positions can be taken in stories that tend towards the monological, having a singular perspective and being somewhat sealed off from others. Alternatively, stories can tend towards the dialogical, a multiple, less certain and more interactive mode. We explore multiple stories of an organizational change and analyse a paradoxical situation that emerges. We argue that although the stories may have the appearance of being dialogical, they can be seen as co-existing but self-sealing, or anti-dialogic. We introduce an interruption to the story and discuss a possibility for challenging anti-dialogic positioning in change stories.
\end{abstract}




\section{Stories and Change}

There is a now an accumulating body of research which recognises organizational change as a multi-storied process in which typically there are competing accounts. Stories can be used as ways of representing, analysing and evoking change. Important thrusts of this research have been to identify dominant stories and the subjugation or silencing of alternatives (Dawson and Buchanan, 2005), the use of stories in gaining legitimacy (Currie and Brown, 2003), and attributing identities (Sims, 2005). In situations of organizational change, stories have forms and relative positions that have consequences for their impact on organizational life. For example, a dominant epic story told by managers can be counter-posed to tragic stories (Brown and Humphreys, 2003), or stories with ironic or romantic forms (Beech, 2000) that are told by other groups in the organization. The positioning of a story relates to the fit between the story and the identities of the storyteller, other characters and the sense that the story helps to make of the situation.

People tell their stories as a way of making sense of their experience of organisation and change (Brown and Humphreys, 2003; Gabriel, 2004) both in retrospective and in prospective ways that guide future perception and behaviour (Ybema, 2004). However, according to Buchanan and Dawson (2007: 669) "much still remains unconsidered in this claim" that change is a multi-storied process. The general aim of this paper is to contribute to the research addressing questions concerning how stories people tell of themselves going through change incorporate and react to those of others adjacent in the situation and what the consequences can be. The 
specific aim is to analyse contested stories of change which lead to what can be regarded as a somewhat paradoxical situation (Lewis, 2000) in which there is a certain self-defeating quality, or unintended consequence, to the stories as they are constructed. In order to do this, we will identify the relationships between, and mutual impacts of, three stories of a change. Particular consequences of the storying of the change will be discussed and a proposition for enhancing dialogue in similar situations will be made.

\section{Stories of the Self-Through-Change}

Stories of change that pervade prescriptive and managerialist literatures are often monological (Buchanan and Dawson, 2007; Czarniawska, 1997) in providing a singular account of the change that presents itself as fact. The epic form in which a hero meets and overcomes a trial (Jeffcutt, 1994) is common. This is exemplified by Parkin (2004) who presents 50 stories that are intended to enable change agents to evoke and manage change more effectively. She reveals the 'story map' that underlies most of the stories as follows:

"1. 'once upon a time' - the status quo where the story begins

2. 'then one day' - the characters encounter some problem

3. 'because of this' - the story changes direction to deal with the problem

4. 'the climax' - the characters deal with the challenge

5. 'the resolution' - the result of the action

6. 'the moral' - the characters learn lessons as a result of their 
This story form is attractive because it fits with broader narratives that pervade Western societies (Berger, 1997) and with the discourse of modernism (Grossberg, 1996). Such stories are persuasive because they do not doubt themselves. They have the clarity and certainty that are the hallmarks of 'good' strategic change management (Barry and Elmes, 1997). They also follow the 'logic of difference and separation' that is constitutive of modernism (Grossberg, 1996). The story starts by distinguishing a new state of affairs from what is constructed as a prior (uninteresting) 'status quo'. The problem is definite and the characters have particular roles that they follow in the script. The 50 stories that Parkin tells are hero-centric. Other characters, such as bystanders, simple folk who need to see things aright and be motivated and those who provide barriers to change, tend to play subservient or passive roles. All the stories have closure and a moral, and the vast majority are success stories. Stories in this style can be seen as monological. For Gergen (1999) monological stories are formed and told from one perspective, are centred on a focal perspective or character and are not amenable to questioning or criticism. Bakhtin's (1981) conception of the monological is that such accounts have an oppressive character in that they monopolise and fix meaning and marginalise alternative voices.

Monological stories have been criticised for failing to reflect the complexity of socially constructed situations (Boje, 2001), for oppressing divergent perspectives and placing considerable constraints on what is viewed as legitimate action (or 
resistance to the monologue) (Czarniawska, 1997) and for failing to enable either a rich understanding of the storyteller (Shotter, 2008) or ourselves as reflexive listeners to others and tellers of our own stories (Cunliffe, 2002). By contrast, dialogical stories entail openness, alternatives, criticism and self-criticism (Shotter, 2006). For Bakhtin $(1981,1986)$ dialogic process is our route to meaning construction. In this view, language is in continuous motion as people draw from the past and put words into motion in new circumstances. Meaning and significance are constructed by the relationship between words and their context-of-use, by the relationship between the speaker and the listener and the internalized associations (e.g. previous experiences and emotions) the speaker has with the words. Hence, in this perspective, dialogue is not merely a communicative process between two people, but is a performance through which characters develop and alter, the meanings of events and possibilities are (re)constructed (Ramsey, 2008) and outcomes remain 'unfinished' (Kornberger, et. al. 2006) as they weave into new tellings and new stories. Thus, dialogical stories are characterised by being relational constructions in which more than one 'reading' of events, character, plot and moral are present.

Stories can be used to attribute qualities and identities to the self and others. When people and organisations face change, increased 'identity work' (Sveningsson and Alvesson, 2003) can occur as people seek to establish self- and other-identities. Storytelling can be a significant part of the interpretative aspect of identity work (Beech, 2008). The storying of identity through change will typically incorporate interaction and identification of both the self and others in which "the self is 
understood in relation to an audience whose real or imaginary responses constantly shape self-presentations" (Czarniawska, 1997: 46). Other characters can play a role in the self-story of change by their words and actions, or an imagination of them being incorporated into the self's own frame of meaning (Blumer, 1969). For example, in the 'looking glass effect' a person develops a view of themselves by imagining how they look from the perspective of others (Blumer, 1969). These concepts of inwardly- and outwardly-focused processes of building/absorbing others into the story of the self are similar to the idea of Hatch and Schultz (2002) who, like Blumer, build on the fundamental concepts of Mead (1934). For Hatch and Schultz (2002), self-identity can be formed primarily through 'expressing', that is the way that members talk about themselves to others. Alternatively, there may be a primacy of 'impressing' in which the perceptions of others leave a strong mark on the self-identification. If the focus is on expressing then problems of narcissism and excessive self-esteem can result. Conversely, if over-emphasis is given to impressing by others, 'hyper-adaptation' can occur where people appear to be heavily influenced by others. Impressive or expressive stories can both be dialogical in that meaning is constructed in the relationship between the self and the other. However, it is also possible for stories in both styles to have a dialogical appearance but to be relatively monological. For example, 'the other' could be largely a fantasized projection and their words and actions be interpreted so as to fit with the self's perception of 'the' story. In short, stories of change can construct others mainly in an outwardly-focused ('transmitting') mode or in a mainly inwardly-focused ('receiving') mode. Further, it is important to emphasize that these differences in focus do not constitute an either/or dichotomy. Both inward and outward emphases 
imply a role for both self and other, for example, a storyteller is still in a process of making and changing their own meanings however outwardly-focused they are. The difference in focus is one of emphasis and there is a range of possibilities between the two extremes.

One consequence of storying of the self-through-change is that boundaries become established. As Silverman (1993) puts it, 'spheres of action' become attributed to actors such that expectations about what is, and what is not, proper for them to do become ingrained. This point is emphasised by Gabriel (2003) who explores the difficulties in escaping character boundaries and Sims (2005) who links identities in stories to limits on behaviour and perception. Hence, stories of change might be expected to construct identities that emphasise and reinforce certain ways of making sense and acting. The aim of this paper is to explore how the stories people tell of themselves going through change incorporate and react to those of others adjacent in the situation. The stories will be analysed to construct an understanding of: the self- and other-identities that inhabit the stories; whether the stories are more inwardly (receive)- or outwardly (transmit)-focused; and how the spheres of action and agency are attributed in the stories.

\section{Method}

Our empirical research was conducted in an organisation that operated in multiple sites in the field of financial services. Access was gained via a senior manager who supported the research, and although we hoped that some learning would occur 
that would be potentially helpful for people in the company, the project was neither consultancy nor action research.

After some initial discussions it was decided to select groupings which represented a hierarchical slice through the organisation. In this case, the groups were senior managers, middle managers, advisors on 'platform 2' and advisors on 'platform 1'. These groups undertook the main activities in service provision and were those most directly involved in the change, but this choice meant that we did not interview other functional groups such as HRM or Marketing. The company operates around the world but our research was in one country where we conducted interviews in the head office and one of the large regional offices. This meant that the stories were gathered from a setting in which everyone identified the major change. During the analysis we looked for alternatives to the initial groupings as we did not want to over-reify the hierarchical order. For example, we explored pro- and anti- change stories and epic and tragic styles. However, we found that the hierarchical groups were strongly represented as roles within each story and in talk about the self and others. Therefore, we present stories below from three of these groups. We do acknowledge that this are not the only story, and so we also present two alternatives as an 'interruption' which indicates some of the diversity in the setting.

We spent 18 months researching with the company which was visited four times during this period, and we interviewed the same 50 participants on each occasion. Our aims in adopting this approach were to build up some trust with the participants, to trace the patterns and changes in their talk over time and to be able 
to 'play back' what we were hearing in order to give them a chance to react. Many of the interviews were group-based which facilitated interaction between participants. Participants were invited to discuss their perspectives on what was happening in the organisation, who was involved in any changes and what they were doing. Participants were also invited to discuss their position relative to others and their sense-making of the situation. During phases $2-4$, some feedback was provided to participants of key issues raised in the previous round of research and they were invited to react to this. In doing this, we were not seeking to 'validate' our 'findings' but to discuss interpretations. After the series of interviews a meeting was held with the sponsor to discuss our analysis, including the stories presented here.

In addition, informal conversations were conducted on and off-site, observations were conducted of the physical environment and social interaction and company documents were accessed. Observations were helpful in combination with the interviews, for example, we were able to ask questions about actions that had been taken, documents that had been produced, and also absences such as the apparent lack of communication that was observed between certain groups.

The interview recordings were transcribed and analysed using a process expounded by Silverman (1993). The stories were examined for recurring themes, characters and actors. We identified the actors' spheres of action informing category-bound activities which formed part of their identity-work. Within the stories there was an ordering (sequence and choice between alternatives) of events and actions. The 
analysis gave an indication of how different groups of actors constructed their own roles, identities and situations, and those of other actors.

One limitation to this method is that it is necessarily selective in the data presented and this provides a partial view of the research material. There was more diversity than is presented here. This research is not intended to tell 'the whole story' (if such were possible) but rather to highlight aspects of stories told that have significance for the research questions under consideration (Grant et al, 2001). We do not purport to have privileged access to the 'true' story of what happened, not least because that would put us in the position of monological storytellers. We sought to give voice to a number of concurrent stories and explore the relationships within and between them. The authorship of these stories, in common with much academic research, is multiple. We would see ourselves as editors or perhaps co-authors with the research participants. We used the words of the participants, but we did select certain stories, summarise lengthy sections of speech, and put together phrases spoken at different times. As the edited versions of the stories were developed, they were played back to the participants who were able to make additions and alterations. Before presenting the stories from three perspectives we will give a brief overview of the context.

\section{NSC Finance}

The organisation involved in this study was an international financial services company which we will refer to as 'NSC Finance'. NSC Finance provides financial planning, asset management and insurance services for institutional and individual 
clients. We have to be somewhat circumspect as we gave an assurance that they would remain anonymous, however, it is important to be aware of certain aspects of the context within which the stories were told. NSC Finance is a well known name, holding a seat on the New York Stock Exchange. The market was expanding at the time of the study, and it was highly competitive with the largest competitor having $4 \%$ of the market and NSC Finance having $2 \%$.

NSC's core strategy was to expand and to gain greater market share. They were profitable and could afford to invest in expansion. Their approach to growth was to significantly increase the number of financial advisors they employed and to motivate them to be entrepreneurial in expanding the client base. This approach was preferred to alternatives such as acquisition of a competitor.

The chosen strategy entailed setting up different 'platforms' of employment. Traditionally, advisors had had standard employment contracts, worked in NSC offices and sold NSC products. Under the new arrangements Platform 1 (P1) employees would continue in much the same way. They would receive a monthly base salary and then $15 \%$ commission on sales above a certain level of revenue. On Platform 2 (P2), employees would be able to sell the products of other companies in order to foster their relationships with clients and build up what was referred to as "their business". They would operate under the brand of NSC Finance but would have to pay for their own office space, as well as paying for compliance, technical and office support. They would not receive the same salary as P1 but they would receive a higher level of commission. A planned further change, Platform 3, would 
constitute a greater degree of independence, with advisors running 'their businesses' without the NSC brand, taking a greater share of personal income from sales, but still paying a small proportion of fees to NSC for processing transactions. This Platform system was new in the industry and NSC perceived themselves to be innovative in taking this approach but the valuing of entrepreneurship and the focus on financial success would be common in the context.

On platform 1 (as had been the case traditionally) new advisors were given leads on new clients and would receive clients from the portfolio of other (platform 1) advisors who left. The training was regarded as industry-leading and advisors attended phone clinics in which they learned to make and develop leads. Higher platforms did not have this level of service, and the more independent they were, the more it would be likely that if they left (either to a competitor or to set up their own company) they would take their clients with them.

\section{Three Stories of Change}

In the stories below direct quotations from the research participants are indicated by quotation marks.

\section{The Senior Managers' story}

We were aiming for market growth for "pretty much the basic reasons any company would enter into such a huge project...the industry is not dominated by one player...looking over time there will be consolidation...maybe 5 or 7 players...we want to be one of those players". We needed to achieve cost-effective growth, and 
the way to do this was through new employment arrangements (P1 and P2) and increasing the number of advisors. "At the time there were 8000 advisors, half were committed to the company, half were unsure what they wanted...they had to make a decision and stick with it." The aim was to expand the workforce to 20000 advisors over 10 years and for those advisors to be far more "committed to growing the business" by increasing the number of clients they had as well as increasing the number of products that each customer bought.

"Once the strategic design was completed, out of 44 market groups, it was tested in 2...the point of testing was to do a better job implementing". The testing uncovered a number of "hurdles", principally a need for communication. The full programme roll-out began with the slogan "It's all about choice" on all the documents, presentations and statements. "I think we did a good job of conveying the strategy of choice."

When they made the choice, two thirds of the advisors opted for P2 and one third for P1. The managers of the P1 workforce were incentivised to recruit more staff, with the key targets being experienced people from rival companies. Once this was starting to 'bed-in', P3 was introduced as a further expansion of the policy.

P1 was working, but had not been quite as successful as expected. "Our intention was to attract veteran advisors, not inexperienced advisors, from other firms with a strong client base...that has not proven to be NSC Finance's strength." Not all have been able to contribute or cope in the new situation "so some had to go 
anyway...dead wood". However, P2 was going well: "It is premature to say whether or not the change is a huge success, especially with the new hires. I'd stay tuned. We are a great company, we've been around for a long time and we can only get more impressive."

\section{The Peons' story}

P1 staff defined themselves as the "peons": "we're the lowest of the low". There was supposed to be a choice of going with P1 or P2, but "we did not have a big enough client base to move to P2, we would lose money". "If you joined after XX date, then you had to be a P1". The new recruits had no experience, so then there were the 'experienced peons' and the 'baby peons'.

No one knew what was going on. "what is going to happen to us? Are we going to get lost in the shuffle? Who are we going to turn to for help?" However, at this stage most of us decided to "wait and see what happens next...it is a good company and I'm sure they'll take care of us". But, we realised our managers ("the Greens") did not have much more experience than us, and "they don't know what is going on". The only thing the managers were interested in was recruiting new P1s: "they want to double the number of us in here....if I am a peon, will I become half a peon?"

Then, things got even worse. Our "basic salaries were redefined as an 'advance' that we had to pay back" by bringing in a certain value of business, and we were 'encouraged' to take a reduction in basic salary to $\$ 18,000$ with a $40 \%$ commission arrangement from a salary of $\$ 30,000$ with a $15 \%$ commission arrangement. "It 
would take an entire year for us to hit that level of business and we would never actually see any commission." We were "completely unsupported by managers and unsure of what is expected". "Family men could not afford to do that". It was "a real blindsided hit from a company that knows it made a huge mistake and is trying to save its ass by blaming us." " The ivory towers [head quarters] said that we had a choice...then they go and change everything after that supposed choice was made....what choice is that?"

"They got what they wanted from us - compliance, and now they want our blood." "You are P1 - they don't care about you and they don't care about me. If they did they wouldn't have done this to us." Peons who could, typically experienced peons, started to leave. Those who stayed thought they were "lucky to have escaped." The recruitment of new baby peons continued.

\section{The Saviours' Story}

For the P2 staff, the "change had been a long time coming" and we had been "held back" under the old regime. The company was "finally doing the right thing." We could be more entrepreneurial now: "I have more control of myself and my business now."

"It took a lot of courage to break away from the comforts of NSC Finance...we were all given the opportunity to be courageous and move to P2...it is this courage and my determination that will see me through." We are "determined to make our business work...we will ultimately save the firm." We are "the only money producers in the 
organisation." We are the productive force: "About $80 \%$ of the company's profit is produced by about $20 \%$ of the advisors, so they should be putting their time and support into developing us more than P1 which is costing the company money".

It is true that P1 were "hit hard with the strategy" but they had had the chance to be courageous. "We were all given a choice...if they don't like it, they should suck it up and get out on their own in P2." But, P1 was basically a drain on NSC Finance: "if this company goes down, it will be because of how much [the headquarters] wastes on wiping those babies' asses." The P1 managers, "the babysitters", "aren't much better than the babies. In fact they may be worse because they aren't focusing on developing their businesses...just babysitting."

"My business is thriving.... am making all the decisions and I haven't looked back." "Everything is great...it's how it should be" except that "P1 will continue to bleed the company...it will be up to us to bail them out because we are the true money makers here." "We are the saviours, trying to get the work done". But we keep getting taxed to keep them going. "The bank robbers [Head quarters] are taking too much money...if I get one more haircut (fee levied on commission), I'll be bald!" "I think many may consider going out on their own without the NSC Finance brand." "If they don't re-examine the fees, l'll look seriously at moving to P3...I don't need the brand anymore...my clients are with me." "Brand is only important for new clients. People are buying the advisor."

\section{Making sense of the sense-making stories}


Clearly, these stories of ostensibly the same change process are indicative of quite distinct sense-making about the experience. The senior managers say that the change constitutes an improvement and hence is uncontroversial in business terms. This was borne out by their actions in rolling out the pilot project and extending it to P3. In the context of their industry, this sort of change would fit with the context which approves entrepreneurialism and financial success (Grossberg, 1996). They could be seen as exhibiting a degree of postalgia (Ybema, 2004) in which the golden future appears to be just around the corner. There may be some "teething troubles" with P1, but there is no question as to whether or not the change will be a success, their only question is how "huge" the success will be. In their story, the self-identity is as strategic decision-makers. Their construction of others is as staff who ought to take the opportunity to develop their businesses and be successful. The story is epic in style and their constructions are mainly outwardly (transmit)-focused as having set the strategic direction (i.e. completing their role-bound sphere of action) they are now awaiting action by others. There is an assumption, which they repeat often, that others have choice and in our interactions with them and, in the view of Sponsor who was part of their group, they were largely unaware of the peons' story. This story can be seen to relate to the context in which it is told. Risk-taking and growth were talked about bullishly with regard to companies and individual portfolios. The story both drew on, and contributed to the entrepreneurial style of talk that was common in the setting. This 'good fit' of the story with its context may have helped it become established and maintained. 
By contrast, the peons express low self-esteem, and things are getting worse in a tragically styled story. Their constructions of themselves are as the "lowest of the low" and they regard others as powerful and uncaring. Whilst they see themselves as unable to overcome the problems that face them, they feel that others who could solve things fail to do so. So, for example, their managers (the Greens) are not able to help them build up their client bases and senior managers appear to be intent on reducing their income without any regard to their needs (particularly the 'family men'). Hence, their own role-bound sphere of action is to await direction and support, and others are constructed as remiss in not providing leadership.

We observed a notable lack of resistance apart and when one peon tried to encourage others to band together and speak up, few were willing to do so. Our interpretation of this was that the peons were fearful of negative consequences and their (non) action was in line with the self- and other-identities that pervaded their story of the change. Much of the story appears to be inwardly (receive)-focused. They define themselves as they believe others see them (Blumer, 1969) and they look to the outside for help and solutions to problems. In one sense, this story does not fit with the context of a growing, confident industry. However, it could be seen as fitting with a broader social context in which some would prioritise safety over risk and think that big businesses were not averse to treating low-status employees badly if it produced higher profit.

The saviours tell a more narcissistic story (Brown, 1997) in which they position themselves as both saviour and victim in that they are unfairly treated by the 
company. Their place in the story is as the agential actors who have the ability to make the business work. Others are regarded as inactive and ineffective, causing a drain on profitability. In the role-bound spheres of action, the saviours are saving, the babies are being saved and the bank robbers are imposing their unfair demands. From this perspective, the others could choose to be different if they were sufficiently courageous, and hence the culpability for problems is attached to the others, not the self. The story is largely outwardly (transmit)-focused as there is little consideration of the perspectives of others, and others exist mainly as bystanders or irritants providing challenges to be overcome by the heroic self in this epic story. Hence, others' purpose is to allow the saviours' story to move forward. After all, if you are going to be a saviour, you do need someone to save. This story, like that of the senior managers, has a good fit with its context. It shares the entrepreneurial vision/fantasy, but adds the oft-repeated complaint about taxes. In a bullish context, this was bullish talk which resonated with the value placed on risk-taking and selfreliance in the industrial context. Table one summarises the interpretation of these narratives.

Insert table one about here

\section{An Interruption}

Cunliffe (2002) has argued persuasively that it is crucial in constructionist and storytelling research that we exercise a degree of reflexivity in which we question how we have written and edited the stories of others for our purpose. As Gabriel (2004) says, it is natural that we privilege our own stories and those of our allies. On 
reflection, it is notable that the stories presented are attributed to hierarchical groups as if those groups have clear and distinct identities. This could reflect the way the data were collected as the stories were told in 'homogenous focus groups' of P1s and $\mathrm{P} 2 \mathrm{~s}$ and by individual senior managers talking to researchers. However, it is also worth noting that the groups did strongly identify themselves and others, and positioned the others as actors in their own stories. There was also physical colocation within groups and both formal task and informal socialisation similarities within group (and difference with out-groups). Hence, we think that it is not unreasonable to attribute the stories to the groups. However, it would be a misrepresentation to say that the groups had absolute singular identities. There were exceptions and other stories in the organization. Given the constraints of paper writing, we again have to be selective in the stories we present, but we want to highlight briefly two from people who did not easily fit into the categories we have used above.

The first exception story is of 'Maverick'. Maverick was a peon. Like other peons, he saw the situation as negative and exploitative. However, unlike others, he was willing to stand up and voice his opinion. He was the source of critical talk behind the scenes with other peons and was also willing to express his views to managers. His view was that the peons could act against the situation. However, eventually he became frustrated and left NSC. Other peons regarded Maverick with a mixture of admiration and disapproval. Once he reached the point of leaving, the others distinguished themselves from him. Maverick was not a 'family man' and could afford to take the chance of a loss of income, whereas they 'had responsibilities'. 
Hence, even through Maverick argued for, and did, something different, their story was able to absorb this by distancing themselves from him.

The second exception story is of our 'Sponsor'. Sponsor was a senior manager and our contact in the company. Although a well-regarded senior manager, his perspective was somewhat different from the norm. This is evidenced not least by the fact that he invited researchers in and was interested in finding out the perspectives of others such as the P1s. Sponsor had a more holistic view and argued within his group that the change was not successful and that adaptation was needed. However, like Maverick, he became increasingly frustrated and also ended up leaving NSC. Once he left, our access quickly became curtailed, but from some subsequent conversations it appears that Sponsor's identity was being reconstructed from 'promising' to 'misguided'. His sort of approach was associated with inefficiency and was unlikely to gain traction in the company.

We introduce these alternative stories to acknowledge that the first presentation of three stories is not a complete representation, and also to trace connections between those who did not fit and the sense-making we discussed above. Although there were exceptions who were critics of the way their in-group told the story, the way that these critical people were coped with actually strengthened the stories. They were reconstructed as outsiders, and the difference of their view was explained away by significant contextual distinctions between him and us (we have responsibilities, he is not a family man) or by dismissal (his approach is inefficient). 


\section{Discussion}

The questions that guided this research concerned how stories people tell of going through change incorporate and react to those of others adjacent in the situation and what the consequences can be. The specific aim was to analyse contested stories of change which lead to what can be regarded as a somewhat paradoxical situation.

The relative positioning has the appearance of dialogue, but this appearance is deceptive. There is multiplicity in that there are different versions of what is happening, why and what it means. There is the appearance of dialogue as each actor group appears as a character in the story of others and their actions (and inactions) are recorded there. However, in two cases the stories were largely in externalising (transmit) mode in which others appeared as necessary characters to allow the story of the self to proceed. The saviours needed someone to save. The senior managers needed others to set a strategy for.

This mode of storytelling (somewhat similar to Parkin's (2004) story map) is not particularly adept at taking in information from the outside. And this is compounded when we consider that the images of the other owe a considerable debt to the imagination of the storyteller. Gabriel (2004) highlights the importance of imagination in stories, and in this context we regard the images of the others as "poetic elaborations" which reveal much about the storyteller (Gabriel, 2004: 75). Although some cues were taken from the other, their operation in the story might be 
regarded as a discursive resource (Watson, 2001). These discursive resources were put to work in establishing and maintaining the story of the self-through-change - a form of identity work (Sveningsson and Alvesson, 2003) - in which interruptions to identity (such as Sponsor, or brief flashes of inconsistent 'feedback' from the other in the shape of Maverick) were discounted or explained away. The characteristics and meaning attributed to the other functioned to enable the story of the self to remain intact.

In the case of the peons, the story was in internalising (receive) mode to a greater extent. For example, others were put in the position of initiating action, meanings were taken from others, and even self-definition was derived from the way they were seen by others (the lowest of the low) rather than as they saw themselves (e.g. family men). When others did not appear to be active in the story, the peons were lost - asking 'what is going to happen to us?' without apparent hope of answer. However, although the other plays a strong role in this story, as with the externalising (transmit) stories, fantasy and imagination are significant in the construction of the other. Our observations were that the peons had minimal interaction with the senior managers and the saviours, and they spoke repeatedly of a lack of communication. However, they constructed the others from minimal materials, and often from silence and inaction, for example, The Greens' distinguishing feature was a failure to help. Similarly, the senior management were interpreted through occasional policy decisions, but were present in their absence, notably in the confusion and concern about what was happening. In discussion with the peons, particularly during the follow-up visits, it seemed clear that they felt that 
something threatening was going on, but they had little idea what. Hence, although the peons were seeking input to their story, they were left scratching around for material and so produced what they could from the bare bones available to them. The others were fleshed out by the peons' (negative) fantasy/imagination of their characters.

Therefore, the multiple strands of this story achieved relative positioning by imagination and projection within the self-story. Both externalising (transmission) and internalising (reception) forms of story projected towards or absorbed a view of the other that was elaborated and embellished through imagination. Although there were multiple story-strands, each group did not hear the stories of the others, and hence, the stories could be regarded as a number of monological stories in proximity to each other, between which there was little engagement. They could be seen as relatively self-sealed stories, relying on the others only to the extent that the others had to be physically present and not do anything that would dramatically disturb their perceived role-bounded spheres of action (Sims, 2005; Silverman, 1993). In this sense, the positioning in each of the stories was anti-dialogic as it militated against genuine engagement and promoted fantasized images of the other.

We turn now to the consequences of these storied processes of construction. First, each group has a low probability of acting outside its sphere of action that defines acceptable behaviour in a role. In the stories the peons remained in their passive role, senior managers remained in their strategy-setting role and the saviours remained within their narcissistic self-image. As the degree of actual dialogue 
between the stories and sense-making of the groups was minimal, the (in)actions of others could be absorbed into the existing story, and even when in-group members, such as Maverick or Sponsor, did something outside the sphere of action, it was possible to 'explain away' such actions, so that the story and its associated character-identities were preserved.

Secondly, a consequence of the composite of the self-sealed stories was that a somewhat paradoxical situation was perpetuated in which some parts of the stories appeared to be self-defeating and to have unintended consequences. The peons expressed a desire to be full and permanent members of NSC in the hope of security and reciprocity from the company. However, they were seen as the least desired character. Those that left were "dead wood" and those that stayed were "babies" and a drain on the system. Conversely, the saviours were constructed as objects of desire (not least by themselves). However, given that they felt both imbued with power and hard-done-by, the likelihood of them staying at NSC Finance was limited. In fact, increasing numbers were leaving or opting for P3 which was akin to independence. But in leaving or opting for a tenuous connection the saviours would fail to save anyone other than themselves. The consequences for senior management were no less serious. Their aim had been to establish major growth in the company by establishing an enlarged and transformed workforce of entrepreneurial employees who would win more clients and more business from existing clients. This aim was espoused in strategy documents, repeated in their talk and could be seen influencing their actions in establishing the new platforms. What happened, however, was that the sense that people made of the situation militated 
in the reverse direction. In something akin to Orwellian (1949) doublethink, 'the more attached you are, the less you are one of us'. Those that most wanted to stay and protect their place in the organisation were the baby peons. Those who most wanted to (and were able to) leave were the saviours and the experienced peons. The entrepreneurial employees were not averse to becoming entrepreneurs. Those who sought security would seek to do whatever it took to stay in place. Hence, although the workforce was growing, it was not increasing the population of entrepreneurial employees, and the proportion of inexperienced people needing support was increasing. Other characters, such as Sponsor and Maverick, who might have had something to contribute, ended up frustrated and leaving.

Thirdly, the likelihood of the problem being solved is remote. Each story is able to identify what the problem is, and who has the responsibility for solving it. Sadly, in these stories, everyone thinks it is someone else. The senior management story is that the problem lies with $\mathrm{P} 1$ and that they have the choice/agency to solve it. The peons' story has a contra-reciprocal construction. They know that the senior managers have agency but they seem unwilling to act ("who are we going to turn to for help?"). In the saviours' story, they know that they have the ability to fund the others but their willingness to do so is low and decreasing, and the solution is in the babies being un-baby-like and the managers being more managerial. Hence, each character knows that the problem lies with the other, and so the obvious action is to wait for them to solve it. So with everyone in 'waiting mode' the likelihood of any character solving the problem as perceived by others is minimal. This apparent 'knowledge' within the stories plays an important role in their anti-dialogic 
positioning because it militates against questioning and self-critique and promotes the appearance of monological certainty regarding the 'finished' or 'complete' nature of the characters and their responsibilities.

\section{Conclusion}

The analysis presented here indicates that the apparently multiple-stranded story might more accurately be regarded as a number of self-sealed stories positioned in proximity but with little engagement. Others were imagined and projected and the consequences were that the separated sense-making left significant gaps in problem-solving and action. It would appear that the 'logic of separation' (Grossberg, 1996) was winning out and the strength of the stories in positioning the storytellers militated against dialogue..

Given all of the above, what might be done in such situations to help matters? Shotter (2006) contrasts 'aboutness' and 'withness' thinking. Aboutness thinking is monological and does not treat others as 'living objects' whose responses could seriously alter the theories one holds of them. In contrast, withness thinking is dialogical and can 'touch' or 'contact' the other in such a way that difference is realised and the response of the other can genuinely impact on the sense made by the self. In order to achieve such dialogue, the other has to be granted the position to make 'action guiding calls' to which the self then has to respond in a way that risks changing the self. In the case examined here it is clear that any withness thinking was outweighed by aboutness thinking in storymaking. Clearly, NSC would be a 'difficult case' however, if we examine Maverick and Sponsor we might see some 
clues about promoting dialogue amongst the self-sealing stories. Dialogue might commonly be thought of as harmonious, but an alternative view of withness thinking is that it entails interruption and the willingness to give and receive discomfort. It is not about the different groups thinking the same thing, but their differences being able to penetrate sealed stories. Sponsor was discomfited by recognising the peons' reality. They interrupted his senior managers' story, although he was unable to adequately interrupt the story of the other senior managers. To be successful, we would argue that withness thinking dialogue also needs to entail the possibility of againstness thinking. Sponsor and Maverick started this. They had enough status in their groups to be able to interrupt the dominant story, they had a disposition to hear other stories and they had a willingness to persist in the face of social pressure to conform. In the end, they were frustrated and left and the stories re-sealed with them out of the picture. However, further research could enquire into how such interruptions could be sustained. This could address issues such as legitimacy, status and processes that promote self-challenge. Withness dialogue should not mean that we tell one story, but that we have ways of accessing the alternative stories that make us uncomfortable.

\section{References}

Bakhtin, M.M. (1981) The Dialogical Imagination, Holquist, M. (ed), Emerson, C. \& Holquist, M. (trans). Austin, Texas: University of Texas Press.

Bakhtin, M.M. (1986) Speech Genres and other late essays. McGee, V.W. (trans.). Austin, Texas: University of Texas Press. 
Barry, D. and Elmes, M. (1997), 'Strategy Retold: toward a narrative view of strategic discourse', Academy of Management Review 22(2): 429-453.

Beech, N. (2000) 'Narratives Styles of Managers and Workers: A tale of star-crossed lovers?' Journal of Applied Behavioural Science 36 (2): 210-228.

Beech, N. (2008) 'On the Nature of Dialogic Identity Work', Organization 15(1): 5174.

Berger, A.A. (1997) Narratives in popular culture, media and everyday life. London: Sage.

Blumer, H. (1969) Symbolic Interactionism: Perspective and Method. Englewood Cliffs, NJ: Prentice Hall.

Boje, D. (2001) Narrative Methods for Organizational and Communication Research. London: Sage.

Brown, A.D. (1997) 'Narcissism, identity and legitimacy', Academy of Management Review, 22(3): 643-686.

Brown, A.D. \& Humphreys, M. (2003) 'Epic and tragic tales: making sense of change', Journal of Applied Behavioural Science 39: 121-144.

Buchanan, D. \& Dawson, P. (2007) 'Discourse and Audience: Organizational change as multi-story process', Journal of Management Studies 44(5): 669-686.

Cunliffe, A.L. (2002) 'Reflexive Dialogical Practice in Management Learning', Management Learning 33(1): 35-61.

Currie, G. \& Brown, A.D. (2003) 'A narratological approach to understanding processes of organizing in a UK hospital', Human Relations 56: 563-586.

Czarniawska, B. (1997) Narrating the Organization: Dramas of Institutional Identity. Chicago: The University of Chicago Press. 
Dawson, P. \& Buchanan, D. (2005) 'The way it really happened: competing narratives in the political process of technological change', Human Relations 58: 845-65.

Gabriel, Y. (2000) Storytelling in Organizations: Facts, fictions, fantasies. Oxford: Oxford University Press.

Gabriel, Y. (2003) Your Home, My Exile: Boundaries and 'Otherness' in Antiquity and Now. Organization Studies 24(4): 619-632.

Gabriel, Y. (2004) 'Narratives, Stories and Texts', in Grant, D., Hardy, C., Oswick, C. \& Putnam, L. (eds) Organizational Discourse. London: Sage.

Gergen, K.J. (1999) Social Construction. London: Sage.

Grant, D., Keenoy, T. and Oswick, C. (2001) Organizational Discourse: Key Contributions and Challenges', International Studies of Management and Organization 31(3): 5-23.

Grossberg, L. (1996) 'Identity and Cultural Studies - Is that all there is?' in Hall, S. \& du Gay, P. (eds) Questions of Cultural Identity. London: Sage.

Hatch, M.J. \& Schultz, M. (2002) 'The Dynamics of Organizational Identity', Human Relations 55(8): 989-1018.

Jeffcutt, P. (1994) 'The Interpretation of Organization: A contemporary analysis and critique', Journal of Management Studies 31(2), 225-250.

Kornberger, M., Clegg, S. \& Carter, C. (2006) 'Rethinking the polyphonic organization: Managing as discursive practice', Scandanavian Journal of Management 22(1): 3-30. Lewis, M.W. (2000) 'Exploring Paradox: Toward a more comprehensive guide', Academy of Management Review, 25: 760-776.

Mead, G.H. (1934) Mind, Self and Society. Chicago: University of Chicago Press.

Orwell, G. (1949) Nineteen Eighty Four. New York: Harcourt-Brace. 
Parkin, M. (2004) Tales for Change: Using storytelling to develop people and organization. London: Kogan Page.

Ramsey, C. (2008) 'Managing to Learn: The social poetics of a polyphonic “classroom"', Organization Studies, 29(4): 543-558.

Shotter, J. (2006) 'Understanding Process from Within: An argument for 'Withness'thinking', Organization Studies 27(4): 585-604.

Shotter, J. (2008) 'Dialogism and polyphony in Organizing Theorizing in Organization Studies: Action guiding anticipations and the contentious creation of novelty', Organization Studies, 29(4): 501-524.

Silverman, D. (1993) Interpreting Qualitative Data. London: Sage.

Sims, D. (2003) 'Between the millstones: a narrative account of the vulnerability of middle managers' storying', Human Relations 56: 1195-1121.

Sims, D. (2005) 'You Bastard: A Narrative Exploration of the Experience of Indignation within Organizations', Organisation Studies 26(11): 1625-1640.

Sveningsson S. \& Alvesson, M. (2003) 'Managing managerial identities: Organizational fragmentation, discourse and identity struggle', Human Relations, 56(10): 1163-1193.

Ybema, S. (2004) 'Managerial Postalgia: Projecting a golden future', Journal of Managerial Psychology 19(8): 825-841. 
Table 1: Summary of interpretation of stories

\begin{tabular}{|c|c|c|c|c|}
\hline & Self-identity & Other-identity & $\begin{array}{l}\text { Inward/ } \\
\text { outward } \\
\text { focus }\end{array}$ & $\begin{array}{l}\text { Agency in } \\
\text { role-bound } \\
\text { sphere of } \\
\text { action? }\end{array}$ \\
\hline $\begin{array}{l}\text { Senior } \\
\text { Managemen } \\
\text { t }\end{array}$ & $\begin{array}{l}\text { - Strategic } \\
\text { decision- } \\
\text { makers }\end{array}$ & $\begin{array}{l}\text { Staff who ought } \\
\text { to develop their } \\
\text { businesses }\end{array}$ & outward & Yes for all \\
\hline Peons & $\begin{array}{l}\text { - Experienc } \\
\text { e-ed } \\
\text { peons } \\
\text { - Baby } \\
\text { peons }\end{array}$ & $\begin{array}{l}\text { - } \mathrm{P} 1 \\
\text { managers as } \\
\text { 'greens' } \\
\text { - } \mathrm{P} 2 \quad \text { as } \\
\text { unachievabl } \\
\text { e } \\
\text { - Senior } \\
\text { managemen } \\
\text { t as callous }\end{array}$ & inward & $\begin{array}{l}\text { No for } \\
\text { peons } \\
\text { Yes for } \\
\text { others }\end{array}$ \\
\hline Saviours & $\begin{array}{l}\text { - Saviours } \\
\text { - Courageo } \\
\text { us } \\
\text { business } \\
\text { people }\end{array}$ & $\begin{array}{l}\text { - } \mathrm{P} 1 \text { as babies } \\
\text { - } \mathrm{P} 1 \\
\text { managers as } \\
\text { babysitters } \\
\text { - Senior } \\
\text { managemen } \\
\mathrm{t} \text { as bank } \\
\text { robbers }\end{array}$ & outward & Yes for all \\
\hline
\end{tabular}


